\title{
Effect of enzymatic treatment on wool fabric
}

\author{
Pooja $^{1} \bowtie$ Sharma E. ${ }^{2}$ and Fatima N. ${ }^{2}$
}

Received: 25.12 .2018

Revised: 28.01.2019

Accepted: 24.03.2019

\begin{abstract}
Wool has been a precious raw material for people for a long time. Today we are able to select between a huge variety of fibres with varying properties, but the continuing use of wool - in spite of the competition with other natural fibres and new synthetic fibres can be attributed to the unique properties of wool such as good thermal regulation, high moisture absorption, low creasing tendency, low flammability and high wearing comfort. However a big disadvantage, which emerges during washing, is the felting tendency. Felting is an undesirable feature of woolen clothes which occurs as a result of the directionally dependent frictional coefficient of the wool fibers. To reduce felting, this directional dependency must be reduced. Nowadays, this is done by treating the wool in a chlorine-containing solution and due to its various advantages; the chlorination is the most frequently used process in the industry today. This process, though effective, results in the production of polluted wastewaters containing large quantities of chloro-organic compounds. Therefore, this procedure has to be replaced and develop clean technologies such as enzymatic finishing processes. Enzymes are natural protein molecules that act as highly efficient catalysts in biochemical reactions. Enzymes not only work efficiently and rapidly, but they are also biodegradable. The present study was undertaken to find the effect of Protease enzyme treatment on wool fabric and the effect of enzymatic degumming on dye ability of wool fabric. The control, scoured and enzyme treated samples were tested for various physical and colorfastness properties. Untreated wool fiber showed fair handle, no absorbency, rough and sharp scales on the surface of fiber, but after enzyme treatment wool fabric showed improvement in all the physical and colorfastness properties. With the single-step enzymatic treatment process, the scales of the wool were partially degraded and resulted in smoother surface structure which will facilitate the sliding of wool fibres in both directions and decrease felting tendency that way.
\end{abstract}

Keywords: wool, enzyme treatment, protease, felting, chlorination, waste water

\section{Introduction}

Eco-friendly processing in textile industry has increased in the current scenario because of increased awareness of environmental issues. Now a days demand of natural fiber products is increasing in the national and international market. The natural fibers are eco-friendly and are easily disposable hence helps in maintaining ecological balance of the environment. Wool, one of the oldest textile fibres known, has survived the test of time because of its unique natural properties. Today there are many other textile fibres, but as yet science has not been able to produce another fibre containing all the natural properties of wool. Wool remains unique; a masterpiece of design. However a big disadvantage, which emerges during washing, Author's Address

${ }^{1}$ Department of Apparel and Textile Science, PAU Ludhiana (Punjab)

${ }^{2}$ Textiles and Apparel Designing, Ethelind College of Home Science, SHUATS, Allahabad (U.P)

E-mail.: poojakaundal0007@gmail.com is the felting tendency. Felting is an undesirable feature of woolen clothes which occurs as a result of the directionally dependent frictional coefficient of the wool fibers. To reduce felting, this directional dependency must be reduced. Nowadays, this is done by treating the wool in a chlorine-containing solution due to its various advantages. This process, though effective, results in the production of polluted wastewaters containing large quantities of chloro-organic compounds. Therefore, this procedure has to be replaced and develop clean technologies such as enzymatic finishing processes. The enzymatic technology is beyond all questions of ecological advantages. This treatment not only gives the fabric a soft handle but also provides smooth and comfortable feel. Enzymes not only work efficiently and rapidly, but they are also biodegradable. Thus keeping in mind these points, the present study was undertaken to treat the woven 
woolen fabric with protease enzyme, to determine the effect of enzyme treatment on dye ability and to find out the effect of protease enzyme on the physical and colorfastness properties of the woolen fabric.

\section{Materials and Method \\ Raw materials}

Coarse woollen (woven) fabric and Alkaline Protease (SCL Pan 5) enzyme were used for the study.

\section{Pre-treatment of woolen fabric}

Before any finishing treatment, the wool fabric must be scoured in order to remove the natural and added impurities that can hinder the successful operation of application of enzyme. Scouring was done as per recipe given by Dantyagi, 2006.

$\begin{array}{ll}\text { Liquid soap (Ezee) } & : 0.5 \% \text { (o.w.f) } \\ \text { M:L } & : 1: 50 \\ \text { Temperature } & : 40^{\circ} \mathrm{C} \\ \text { Time duration } & : 30 \mathrm{~min}\end{array}$

A detergent solution containing $0.5 \mathrm{ml}$ of ezee per $100 \mathrm{ml}$ of water was prepared maintaining the material liquor ratio $1: 50$. It was heated to $40^{\circ} \mathrm{C}$. Wool fabric was dipped into this solution and stirred gently to about 30 minutes. It was kneaded and squeezed in soap solution and then rinsed under tap water. After that fabric was dried in shade.

\section{Enzyme treatment}

Enzyme treatment was carried out on woven woollen fabric using alkaline protease (SCL Pan 5) enzyme having activity of $5000 \mathrm{u} / \mathrm{gm}$. The following recipe, given by Udakhe et al. (2012), was used for enzyme treatment of woollen fabric.

$\begin{array}{ll}\text { Alkaline protease } & 4.0 \% \text { (o.w.f) } \\ \text { M:L } & : 1: 20 \\ \text { Temperature } & : 40^{\circ} \mathrm{C} \\ \text { Time } & : 60 \mathrm{~min} \\ \text { pH } & : 8.5\end{array}$

The solution for enzymatic treatment was prepared by maintaining the material liquor ratio 1:20. The temperature was raised and maintained at $40^{\circ} \mathrm{C}$. fabric sample was added to solution and treated for 60 minutes. After that, the sample was taken out and transferred into acidic solution having p.H 5 for
20 minutes to stop the enzyme activity at the point and then rinse with cold water.

\section{Testing for physical properties}

All the samples (control, scoured and enzyme treated) were subjected to various testing for physical properties in order to check the effect of treatment on these properties (Table 1).

\section{Table 1. Showing test and their standard}

\begin{tabular}{|l|l|l|}
\hline SN & TEST & TEST STANDARD \\
\hline 1. & Absorbency & AATCC:79-1995 \\
\hline 2. & Fabric drape & ASTM D-737 \\
\hline 3. & Fabric tensile test & BIS:4303-1968 \\
\hline 4. & Hand of fabric & \\
\hline 5. & Pilling resistance & IS:10971-1984 \\
\hline 6. & $\begin{array}{l}\text { SEM(scanning } \\
\text { electron microscopy) }\end{array}$ & ZEISS EVO 50 \\
\hline 7. & Weight loss & ASTM d 2720-94 \\
\hline
\end{tabular}

\section{Dyeing of wool fabric}

All the wool samples i.e. control, untreated, scoured and enzymes treated were dyed with acid dye in order to find out the effect of enzyme treatment. The following recipe given by Shenai, 1976 was used for dyeing of samples.

$\begin{array}{ll}\text { Acid dye } & : 10 \% \text { (o.w.f.) } \\ \text { Glaubers salt } & : 15 \% \text { (o.w.f.) } \\ \text { Sulfuric acid } & : 4 \% \text { (o.w.f.) } \\ \text { M:L } & : 1: 30 \\ \text { Time } & : 45 \mathrm{~min} \\ \text { Temperature } & : 40^{\circ} \mathrm{C}\end{array}$

Dye paste was prepared by dissolving required amount of dye in small amount of water and Sulfuric acid. More water was added to make the dye solution, keeping the material to liquor ratio 1:30. The samples were added to dye bath. Temperature was raised and maintained upto $60^{\circ} \mathrm{C}$ for 20 minutes and then it was raised near to boiling for 45 minutes, stirring was continued to ensure uniform dyeing. After dyeing the dyed samples were taken out from the dye bath, rinsed thoroughly with water and were dried under shade.

\section{Colourfastness testing of dyed samples}

All the dyed samples were subjected to colour fastness tests which (Table 2). 
Table 2. Showing testand their numbers

\begin{tabular}{|c|c|c|}
\hline $\begin{array}{l}\mathbf{S} \\
\mathbf{N}\end{array}$ & TEST & TEST NUMBER \\
\hline 1. & Colourfastness to light & $\begin{array}{ll}\text { AATCC-RA } & 52, \\
1974 & \end{array}$ \\
\hline 2. & $\begin{array}{l}\text { Colourfastness } \\
\text { washing }\end{array}$ & IS:3361-1979(test-2) \\
\hline 3. & $\begin{array}{l}\text { Colourfastness } \\
\text { rubbing }\end{array}$ & $\begin{array}{l}\text { AATCC-RA } \\
1974\end{array}$ \\
\hline 4. & $\begin{array}{l}\text { Colourfastness } \\
\text { perspiration }\end{array}$ & $\begin{array}{l}\text { AATCC-RA } \\
1975\end{array}$ \\
\hline
\end{tabular}

\section{Statistical Analysis:}

The data recorded during the course of investigation was subjected to statistical analysis as per method of Analysis of Variance. The significance and non-significance of the treatment were judged with the help of ' $F$ ' variance ratio test. Calculated ' $F$ ' value (variance ratio) was compared with the table value of ' $F$ ' at $5 \%$ level of significance. If calculated value exceeded the table value, the effect was considered to be significant.

\section{Results and Discussion}

All the samples (control, scoursd and enzyme treated) were subjected to various testing and the results are discussed as follows:

\section{Physical properties of woollen fabric after enzymatic treatment: \\ Hand of the fabric}

The effect of enzyme treatment on the hand (feel) property of woollen fabric (smoothness and softness) was evaluated by subjective evaluation. It is evident from table 3 that, the texture of control sample was fair (2), while scoured samples became smooth as compared to control sample and it showed good smoothness (3). In case of protease enzyme treated fabric it was found that with the enzyme treatment, the fabric softness and smoothness got increased. The fabric showed excellent softness and smoothness (5). Statistical analysis also revealed that there was significant effect on hand property of woollen fabric.

\section{Weight Loss (\%)}

The effect of enzymatic treatment on weight loss of woollen fabric was studied and it was reported (table1) that scoured sample showed minimum weight loss $(0.52 \%)$ as compared to enzyme treated sample. After enzyme treatment the loss in weight increased. Enzymatic treatment result in the dissolution and destruction of the protruding fibres present on the surface of the fabric, therefore a weight loss was noticed after the treatment. Silava and cavaco (2003), have also reported that an effective enzymatic treatment results in the removal of protruding fibres and therefore a weight loss is expected. It was observed by Angappan et al. (1993), that oxidizing agent attack the cystine linkage bonds which leads to weight loss. Statistical analysis also revealed that there was significant effect of enzymic treatment on weight loss of woollen fabric.

\section{Scanning Electron Microscope (SEM) Test}

SCM test was carried out for control, scouring and enzyme treated fibres to study surface morphology of wool fibres using two magnifications i.e. $2.00 \mathrm{~K}$ $\mathrm{X}$ and $5.00 \mathrm{~K} \mathrm{X}$ and these are shown in plates 1 to 3. SEM images showed that untreated wool fibre was rough and scales were sharp. As it can be seen from the SEM images that, surface scales of wool fibre got blunt and the smoothness of surface was found to increase with enzyme treatment and subsequently increase in the comfort factor of wool.

\section{Pilling Tendency}

The effect of enzyme treatment on the pilling tendency of the woollen fabric was studied using rating standard of pilling and the results are reported in table 1. It is evident from the results that control and scoured samples showed no pilling (5) whereas in case of enzyme treated sample, the pilling tendency increased but slightly. This may be due to weakening of fibres as proteolytic enzymes damage the surface cuticle and cortex region also up to some extent. Udakhen et al. (2012), reported that enzyme can penetrate into the core of the fibres, and cause damage to the cortex region apart from damaging the surface cuticle. Statistical analysis also revealed that there was significant effect of enzymatic treatment on pilling tendency of woollen fabric.

\section{Fabric Absorbency}

All the samples (controlled, scoured and enzyme treated) were subjected to absorbency test. It was found that the control sample showed no absorbency within 60 seconds and after scouring it was improved and took maximum 45 seconds time 
for water to absorb completely by the fabric. It was also found that after enzyme treatment, the absorbency of fabric improved (33 seconds), which means that proteases treatment helped to remove some of the hydrophobic compounds on wool surface. Shenai (1984), also reported that absorbency of fabric can be enhanced by various pretreatments including scouring, degumming, softening treatment etc. by removing various impurities like waxes, oils, fats, natural gum etc. that make the fabric less absorbent.

Table 3. Effect of Proteases enzyme treatment on Physical properties of woollen fabric

\begin{tabular}{|c|c|c|c|c|c|c|c|c|c|}
\hline \multirow[t]{2}{*}{$\begin{array}{l}\mathbf{S} \\
\mathbf{N}\end{array}$} & \multirow[t]{2}{*}{ Sample } & \multicolumn{2}{|c|}{ Hand of fabric (Rating) } & \multirow[t]{2}{*}{$\begin{array}{l}\text { Weight } \\
\text { Loss } \\
(\%)\end{array}$} & \multirow[t]{2}{*}{$\begin{array}{l}\text { Absorbency } \\
\text { (Time taken } \\
\text { in seconds) }\end{array}$} & \multicolumn{2}{|c|}{$\begin{array}{l}\text { Fabric tensile } \\
\text { strength } \\
\text { (newton) }\end{array}$} & \multirow[t]{2}{*}{$\begin{array}{l}\text { Fabric } \\
\text { drape (\%) } \\
\qquad \text { F }\end{array}$} & \multirow[t]{2}{*}{$\begin{array}{l}\text { Pilling } \\
\text { Rating }\end{array}$} \\
\hline & & Softness & Smoothness & & & Warp & Weft & & \\
\hline 1. & Control & 2 & 2 & - & 60 & 42 & 40 & 0.85 & 5 \\
\hline 2. & Scoured & 2 & 3 & 0.52 & 45 & 40 & 36 & 0.75 & 5 \\
\hline 3 & $\begin{array}{l}\text { Enzyme } \\
\text { treated }\end{array}$ & $5^{*}$ & $5^{*}$ & $5.36^{*}$ & $33^{*}$ & 32 & 32 & $0.48^{*}$ & 4 \\
\hline
\end{tabular}

\section{Tensile strength}

The strength test of control, scoured and enzyme treated fabrics was carried out in both warp and weft directions. The data from table 1 reveals that after enzyme treatment, the strength values in both warp and weft direction got decreased. Enzymatic treatment leads to decrease in the tensile strength, which was in accordance with the results of weight loss. As the weight loss increased, the also strength decreased, which was due to the hydrolysis of protein chains due to treatment with proteases. With hydrolysis, the length of polypeptide chains in the proteins of wool decreases, and a lower energy is needed for the separation of chains and breakage of the fabric (Ramin and Montazer, 2010). Statistical analysis also revealed that there was significant effect of enzymatic treatment on tensile strength of wool fabric.

\section{Drapability}

The effect of enzymatic treatment on the drape of the fabric was carried out ans the results are reported in table 1 . The highest percent value of drape shows minimum drapability. It was observed that the control sample showed highest value (0.85) of drape which represented minimum drapability. This may be due to the reason that the presence of various impurities like fats, oils, waxes and starch make the fabric stiffer which ultimately contribute to lower drapability. However enzymatic treatment removed these impurities so the treated and scoured samples showed better drapability than control fabric. It was found that after finishing treatments (scouring and enzymatic treatments) the drapabilityof the fabric got improved (0.48). Statistical analysis revealed that the there was significant effect of enzymatic treatment on drapability of wool fabric.

\section{Colourfastness testing of wool fabric dyed with} acid dye.

All the dyed samples (control, scoured and enzyme treated) were subjected to colourfastness to light, washing, crocking and perspiration

\section{Colourfastness to light}

It has been reported that during fastness test colour changed, which may be due to fading, darkening, change of hue or bleeding. Light is the most important factor responsible for fading of dyed fabrics as it tends to destroy the colouring matter and the result is well known defect of 'fading' while the coloured textile becomes paler and duller. In the study, fading was taken as a criterion for light fastness of dyed samples dyed with acid dye. Fading of samples were evaluated by comparing the exposed and unexposed portions of the samples using grey scale rating and the results for the light 
fastness of samples are presented in the table 4 . Results reveals that control and scoured samples dyed with acid dye showed very good (6), and excellent (7) light fastness respectively while enzyme treated sample showed outstanding results with 8 rating.

\section{Results of Colourfastness to crocking/rubbing}

Crocking fastness test for the samples was conducted both in wet and dry state and the results are reported in Table 4. Results of the table reveals that the control and scoured samples of wool fabric showed very good (4) and very good to excellent rubbing fastness with dry test cloth respectively and noticeable to slight (3/4) colour staining for wet crocking (Figure 1). It is clear that enzyme treated sample gave best results for rubbing fastness with acid dye in both dry and wet state. It showed very good to excellent rubbing fastness and slight staining for wet crocking.

Table 4. Effect of Acid dye on colourfastness properties of woollen fabric.

\begin{tabular}{|c|c|c|c|c|c|c|c|c|c|c|c|c|}
\hline \multirow{4}{*}{$\begin{array}{l}\mathbf{S} \\
\mathbf{N}\end{array}$} & \multirow[t]{4}{*}{ Samples } & \multirow{4}{*}{$\begin{array}{l}\text { Colour } \\
\text { fastnes } \\
\text { s to } \\
\text { light }\end{array}$} & \multicolumn{4}{|c|}{ Colourfastness to } & \multicolumn{6}{|c|}{ Colourfastness to perspiration with Acid dye } \\
\hline & & & \multicolumn{2}{|c|}{ washing } & \multicolumn{2}{|c|}{$\begin{array}{l}\text { Crocking } \\
\text { /Rubbing }\end{array}$} & & & & & & \\
\hline & & & \multirow[t]{2}{*}{$\begin{array}{l}\text { Colour } \\
\text { change }\end{array}$} & \multirow[t]{2}{*}{$\begin{array}{l}\text { Colour } \\
\text { staining }\end{array}$} & \multirow[t]{2}{*}{ Dry } & \multirow[t]{2}{*}{ Wet } & \multicolumn{2}{|c|}{ Staining (wool) } & \multicolumn{2}{|c|}{$\begin{array}{l}\text { Staining } \\
\text { (cotton) }\end{array}$} & \multicolumn{2}{|c|}{$\begin{array}{l}\text { Change in } \\
\text { colour }\end{array}$} \\
\hline & & & & & & & : & 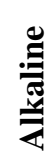 & 른 & 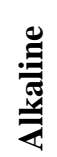 & 을 & 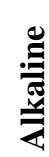 \\
\hline 1 & Control & 6 & $3 / 4$ & $3 / 4$ & 4 & $3 / 4$ & $2 / 3$ & 2 & 3 & 3 & $4 / 5$ & $\begin{array}{l}4 / \\
5\end{array}$ \\
\hline 2 & Scoured & 7 & 3 & 3 & $4 / 5$ & $3 / 4$ & $2 / 3$ & 2 & 3 & 3 & $4 / 5$ & 4 \\
\hline 3 & $\begin{array}{l}\text { Protease } \\
\text { enzyme } \\
\text { treated }\end{array}$ & 8 & $3 / 4$ & 4 & $4 / 5$ & 4 & 3 & 3 & 4 & $3 / 4$ & 5 & $\begin{array}{l}4 / \\
5\end{array}$ \\
\hline
\end{tabular}

\section{Results of Colourfastness to washing}

The rating for washing fastness is given on the basis of change in colour as well as staining on adjacent test fabrics i.e. cotton. Grey scale was used to evaluate both change in colour and staining. The results of colourfastness to washing are reported in Table 4. The result from the table represents that the control samples showed good to very good colourchange (3/4) and noticeable to slight colour staining (3/4). Scoured samples showed good (3) colour change and noticeable (3) colour staining. While enzyme treated sample gave best results for colour change and colour staining i.e good to very good (3/4) colour change and slight staining (4) in both the cases.

\section{Results of Colourfastness to perspiration}

Colourfastness to perspiration is a very important factor for the fabrics used for apparels. Results of the test for dyed samples, dyed with acid dye were tested both against acid and alkali solutions of perspiration and are reported in Table 4. The rating for perspiration is given on the basis of change in colour as well as staining on adjacent test fabrics i.e. cotton and wool. Results from the table reveals that the control sample of wool fabric showed very good to excellent (4/5) perspiration fastness in both acid and alkaline solution. Moving towards enzyme treated sample showed excellent (5) colour change in acidic medium and very good to excellent (4/5) colour change in alkaline medium. Results for 


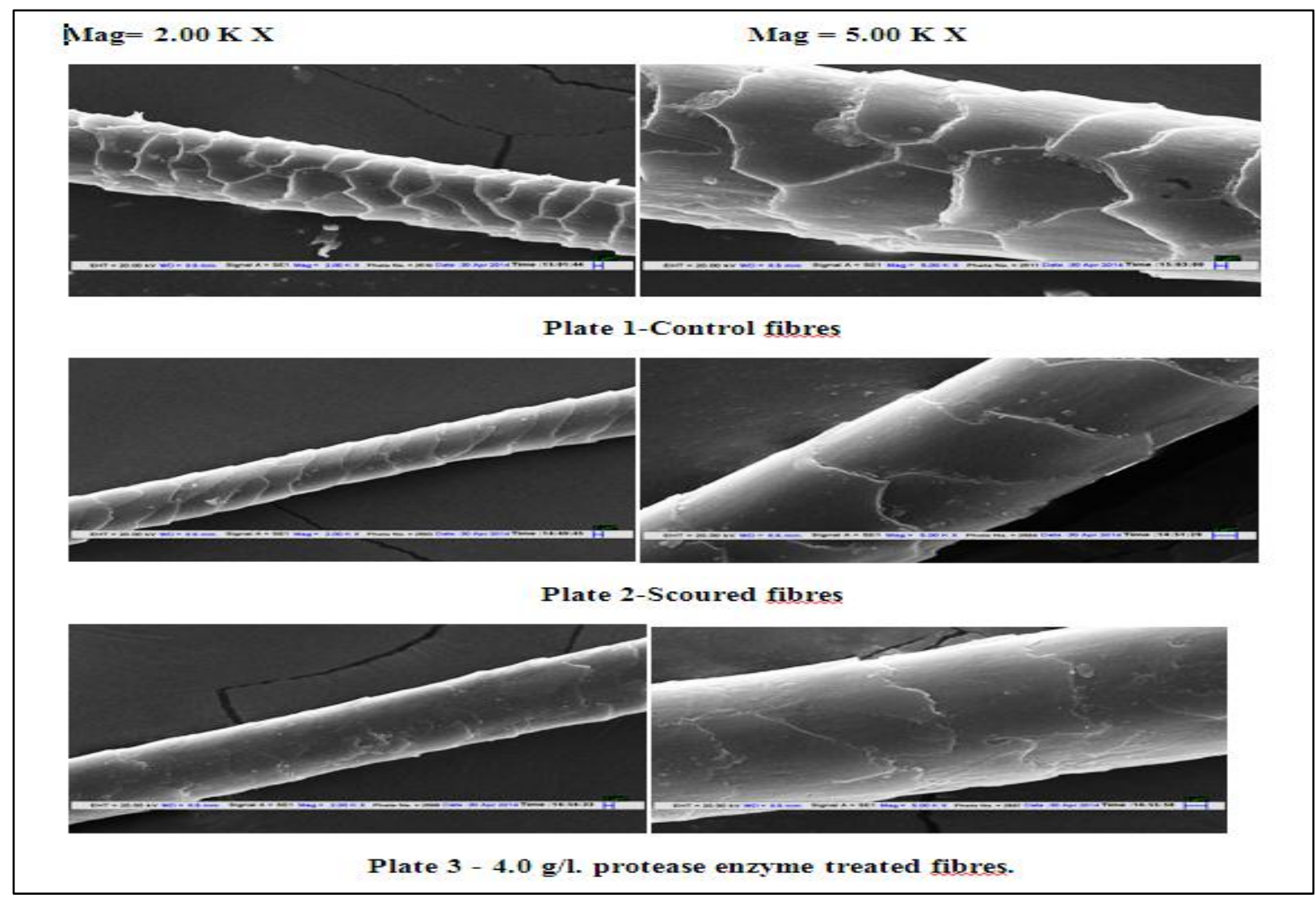

Fig 1. Showing plate 1, 2 and 3

colour staining on cotton fabric shows that cotton fabric gave noticeable (3) colour staining for control sample in both the solutions. Whereas in case of enzyme finished fabric depicted noticeable to slight (3/4) colour staining for alkaline solution and slight staining (4) in acidic solution. Whereas results for colour staining on wool fabric reveals that control fabric had considerable (2) staining in alkaline medium and considerable to noticeable $(2 / 3)$ staining in acidic medium. For enzyme finished wool fabric showed best results i.enoticeable (3) colour staining in both alkaline and acidic solutions. It can be concluded that colour staining on cotton fabric gave best results as compared to wool fabric in both alkaline and acidic medium.

\section{Conclusion}

Enzyme treatment on woven woollen fabric brought the scales flatten thereby made the fabric smooth and soft. It also improved other physical properties including hand, drapability, absorbency, dye ability and colourfastness properties. While tensile strength decreased slightly. It improved the softness and thereby reduced the subjective prickle of the fabric. Statistical analysis also revealed that there was significant effect of different concentrations of enzyme on physical properties of woollen fabric. Hence it can be concluded that enzyme treatment with proteolytic enzyme improved the softness and reduce the subjectively perceived prickle of fabric.

\section{References}

AATCC Technical Manual 2010. Technical Manual of the American Association of Textile Chemists and Colorists. Research Triangle Park, N.C., USA

ASTM. 2012. American Society for Testing and Materials, Pennsylvania, United States.

Angappan, P. and Gopalkrishhnan. R. 1993. Textile Testing. $3^{\text {rd }}$. Tamil Nadu. S.S.M.I.T.T. Students Co-op. Stores Ltd.: 485.

Bureau of Indian Standards 2010. Bureau of Indian standards Publication, ManakBhawan, New Delhi. 


\section{Effect of enzymatic treatment on wool fabric}

Dantyagi, S. 2006. Fundamentals of Textiles and their care, Orient Langman Ltd., New Delhi. $5^{\text {th }}: 154-161$.

Ramin, M. and Montazer, A. 2010. Influence of Proteases and Trans-gluminases on wool. Fibres and Textiles in Eastern Europe. 2(79): 98-102.

Shenai, V. A. 1984. Technology of Textile Processing: Technology of Dyeing. 6th ed. Bombay, Sevak Publication: 490.
Silva, C. J. S. M. and Cavaco-Paulo, A. 2003.Treatment of animal hair fibers with modified proteases. Patent WO03097927.

Udakhe, J., Tyagi S., Srivastava N., Honade S. and Bhute A. 2012. Effect of yarn hairiness, DBD plasma and enzyme treatment on itching propensity of woollen knitwear.Colourage, 59(5): 46-51.

http://www.astm.org/Standards/textile-standards.htm 